\title{
Feminist Ethics Amid Covid-19: Unpacking Assumptions and Reflections on Risk in Research
}

\section{Constance Dupuis}

\section{INTRODUCTION}

My academic trajectory has been guided by my interest in research's ethical entanglements - the possibilities and the responsibilities of research. An early encounter with these entanglements was, for me, the work of Maori Indigenous education scholar Linda Tuhiwai Smith. I have been troubled and deeply challenged by Smith. She begins the groundbreaking volume Decolonizing Methodologies: Research and Indigenous Peoples as follows:

C. Dupuis $(\varangle)$

International Institute of Social Studies, Erasmus University Rotterdam, The Hague, The Netherlands

e-mail: dupuis@iss.nl

W. Harcourt et al. (eds.), Feminist Methodologies, Gender, Development and Social Change, https://doi.org/10.1007/978-3-030-82654-3_3 
From the vantage point of the colonized, a position from which I write, and choose to privilege, the term 'research' is inextricably linked to European imperialism and colonialism. The word itself, 'research', is probably one of the dirtiest words in the indigenous world's vocabulary. (Smith, 2012: 1)

Though I did not grow up knowing and feeling research's role as a tool of domination, Smith, and others teach me about the non-innocence of research.

On the surface, Smith is speaking out against dominant forms of research that are rooted in positivism's quest for the truth and extractive inclinations which seek to do research on and about people, rather than with and for people. There is also a deeper questioning of the drivers of knowledge production; why and for whom is knowledge sought? At what cost? And perhaps most importantly: whose role is it to answer these questions? Who should set the terms within which research takes place? I begin here not to argue that research is unredeemable, but to underscore what is at stake when research goes wrong. As Unangax scholar Eve Tuck and co-author Wayne Yang put it, "as fraught as research is in its complicity with power, it is one of the last places for legitimated inquiry. It is at least still a space that proclaims to care about curiosity" (2014: 223). Tuck and Yang underscore that curiosity is worthy of nurturing in research, while simultaneously cautioning that "[r]esearch is just one form of knowing, but in the Western academy, it eclipses all others" (ibid.: 237). This brings me back to the importance of the questions I pose above. In grappling with these questions, Black feminist thinker bell hooks has been another guide for me. She speaks of theory as without the possibility of purity; theory, and by extension research, is what we make of it. "Theory is not inherently healing, liberatory, or revolutionary. It fulfils this function only when we ask that it do so and direct our theorizing towards this end" (1994: 61). From this, I take the possibilities and responsibilities of doing research. If research, as Smith says, is a dirty word, how can research also be otherwise? ${ }^{1}$

l "Otherwise" has become shorthand to signal a questioning of Eurocentric norms and understandings which emerged from within Latin American decolonial and postdevelopment thinking and beyond (Icaza, 2017; Escobar, 2007; Walsh, 2012, 2016). 
Currents of critical feminist and decolonial ${ }^{2}$ ethics speak to the possibilities of research which centers values other than those dictated by dominant forms of research. When it came time to design a doctoral research project, I felt a responsibility to pursue research rooted in relational ethics. Eve Tuck and Monique Guishard describe the need for a commitment to relational ethics in research:

Decolonial research necessitates a posture to ethics that frames discussions of ethics away from an emphasis on procedures that attempt to safeguard individual rights and autonomy towards conversations about relational ethics in which partnership, commitment, accountability, and social justice are central tenets. (2013: 3-4)

Who is my research for? Who am I accountable to? These are questions that guide me.

These understandings of ethics in research stand in stark contrast to understandings of ethics enacted through institutional ethics review processes. Speaking to the "(im)possibilities of becoming an ethical researcher", Halse and Honey discuss how institutional ethics processes establish normative understandings which limit possibilities for more full understandings of feminist research ethics (2005: 2155). Such processes do not account for the fluidity and time required for establishing and maintaining relational ethics, instead of reducing research ethics to the procedures set out by institutions (Cahill et al., 2007: 307). Matt Bradley (2007), in an article entitled "Silenced for their own protection: How the IRB [Institutional Review Board] marginalizes those it feigns to protect", highlights the frustrating contractions by which institutional ethics processes inhibit the possibilities for more robust participatory ethics through a strict adherence to narrow understandings of research ethics. "These requirements are part of a bureaucratised higher education space that frames the Ph.D. thesis as a 'product' of a knowledge production process guided by neoliberal logics of efficiency, speed and value for money" (Millora et al., 2020: 11). Such logics run counter to the kinds of relational ethics I hope to enact in my Ph.D. project.

${ }^{2}$ I claim neither a complete understanding of feminist and decolonial perspectives on this topic, nor that these are the only locations for such possibilities to thrive. These are the methodological conversations which inspire me. 
The focus of my research is aging, intergenerational care, wellbeing in later life, and exploring what possibilities lie at the intersection of aging and environment. I came back to academia for my doctorate, like many of my peers, with ambivalence about the university and uncertain about whether to pursue the competition and isolation of an academic career. I came back for the possibilities of learning from and with others; I came back for the luxury of time, being able to sink into the telling of wellworn stories; I came back to be able to learn from my biological and adoptive grandparents.

I was prompted to explore these themes within the context of an Innovative Training Network ${ }^{3}$ in feminist political ecology. Though the topic of aging and old age was a new research focus for me, I understood this work as building on earlier engagements with cultivating justice-oriented relations. I had the privilege of growing up in a multigenerational household and in a community that modeled many ways of living intergenerationally. As a Canadian settler of French, Irish, Scottish, and English ancestry from Toronto, I am still learning to contend with the individual and collective responsibilities to disrupt and dismantle settler colonialism. As I move out of early adulthood, questions of age and aging have also begun to feel real for me in an embodied and emotional way. I admit that within my own academic circles, I had encountered very few examining what it means to age well. I have since learned that these are conversations taking place in many contexts, and my hope is to carve out space for serious consideration of old age and aging within feminist political ecology. At the core of my research, I am interested in how learning deeply across difference-inter-generationally, inter-culturally, inter-cosmologically-can have transformative outcomes.

I was introduced to dominant ideas about aging by examining the biopolitical projects of "successful" aging and "active" aging that have emerged primarily from the United States and Europe respectively. Both discourses construct fairly narrow normative frameworks of what later life should look like. I quickly began asking questions about how such ideas

\footnotetext{
${ }^{3}$ Wellbeing, Ecology, Gender and cOmmunity (WEGO) is funded through the European Union's Marie Skłodowska-Curie program.

${ }^{4}$ Picture an advertisement for a seniors' living community, with a wealthy, white, ablebodied, heterosexual couple with perfect smiles lounging by a swimming pool. Such depictions of old age are the embodiment of active and successful aging, and they construct understandings of failure in old age as a failure to achieve such a lifestyle.
} 
limit our imaginaries of what it means to age well (Katz \& Calasanti, 2015; Lamb et al., 2017; Ranzijn, 2010; Rubinstein \& de Medeiros, 2015; Sandberg \& Marshall, 2017; Wellin, 2018). I wanted to learn from other imaginaries of what the end of a life well-lived could be. I had planned to focus on different collectives of older people, in both Uruguay and Canada, who are actively reimagining and creating the possibilities to age how they want to, beyond the logics of dominant discourses. I had hoped, as I will discuss below, to learn from these hopeful experiments in living well.

The Covid-19 pandemic and the resulting emotional, social, and economic upheaval have shed light on assumptions in my research. While I knew I would inevitably get some things wrong in the research process, I was surprised to be confronted with assumptions that I hadn't realized I had made as core to my research. Having arrived in Uruguay in the last week of February 2020, I was three weeks into a several months research stay when questions about the ethics of seeing older people faceto-face surfaced for me. Only when a global health crisis meant that my physical presence had become a threat to my research collaborators did I realize that my being non-threatening was a core assumption of my research design. I believe this gap in my own self-reflection has something interesting to add to discussions about ethics in feminist research.

In the context of a volume on feminist research methodologies, I set out to explore the complexities of navigating feminist research ethics in the context of a pandemic. This chapter begins by situating how I entered the research process and where my thinking about research ethics began, discussing how my assumptions were partially validated in my early data collection. I then explore how the Covid-19 pandemic has flipped some of these assumptions on their head, underscoring some of the unexamined ageism that fed these assumptions. I also reflect on how my understanding of risk in research has been problematized as a result of Covid-19. I close with a reflection on feminist research ethics as a practice of feminist methodologies, and gesture toward how I might put what I have learned about unpacking assumptions into practice.

\section{Starting Points}

We, each of us, carry our histories and our experiences with us into the research process. Often called biases, these are the impacts of how our lives have shaped us. We are marked by our chosen and socially 
imposed identities, these shape what we notice, how we think, how we feel. While some currents of research claim to produce knowledge from a place of objectivity, many feminist (and other) researchers argue that our experiences inform and enhance our ability to ask questions and seek understanding. Feminist contributions to knowledge production have had important impacts on methodology and on how to pursue knowledge. Strong objectivity (Harding, 1995), standpoint theory (Collins, 1986) and situated knowledge (Haraway, 1988) have had profound effects on how critical research is done. Through reflexivity and an engagement with one's own positionality, we can better understand how our identities and experiences shape both our perspectives and how we are in relation with those whom we engage in our research (Harcourt \& Nelson, 2015). Farhana Sultana offers the following:

A reflexive research process can open up the research to more complex and nuanced understandings of issues, where boundaries between process and content can get blurred. [...] Being reflexive is important in situating the research and knowledge production so that ethical commitments can be maintained. Often ethics are then shifted away from the strict codes of institutional paperwork, towards moral and mutual relations with a commitment to conducting ethical and respectful research that minimizes harm. (Sultana, 2007: 376-377)

The importance of the research process figures centrally in both feminist and decolonial approaches. Decolonial thinkers push us further, asking researchers to grapple with the complexity and possibility of understanding our plural positionalities (Icaza, 2017).

Opaskwayak Cree scholar Shawn Wilson teaches us that a central idea of dominant research paradigms is "that knowledge is seen as being individual in nature. This is vastly different from the Indigenous paradigm, where knowledge is seen as belonging to the cosmos of which we are a part and where researchers are only the interpreters of this knowledge" (Wilson, 2008: 38). Though my research focus isn't precisely situated within Indigenous contexts, this understanding of researchers as knowledge interpreters resonates deeply with the kinds of research ethics I am hoping to enact. I approach the role of interpreter with the perspective that, "rather than the truth being something that is 'out there' or external, reality is in the relationship that one has with the truth" (Wilson, 2008: 73). This research has been, for me, a process of learning to see knowledge as relational. 
Though by no means the standard around the world, I grew up in a context where institutionalized care for the elderly is the norm. Despite this, I feel fortunate to have had many examples within my family and in my community of cross-generational care. Here I do not intend to vilify care institutions, ${ }^{5}$ but I see one of the broader purposes of my doctoral research as critiquing the current capitalist system which makes such institutions necessary. The neoliberal retrenching of the provisioning of public services such as care institutions and the resultant proliferation of for-profit care has furthered the commodification of care (Fabbre, 2015; Rubinstein \& de Medeiro, 2015). Simultaneously, the increased separation between older people and the rest of society in many western contexts has allowed for a devaluing of older voices, experiences, and knowledges. I see my research as not only spending time with older people, which some colleagues have found to be a sweet but not particularly serious research focus, but also as looking for absences and listening to silences. How can we (re)build intergenerational bridges?

As a relatively young woman, I began thinking about the discursive politics of what constitutes "success" in later life without the material and emotional weight of these discourses. "Unlike other hierarchies, in which the privileged rarely become the oppressed, we all face age oppressions if we live long enough" (Calasanti et al., 2006: 2). Despite the hope that I will have the opportunity to grow old myself, being elderly is not my everyday. Calasanti et al. (2006) also present age as a political location, paralleling race, gender, class, or ability relations, and underscore the importance of taking age seriously in intersectionality. Though I might not feel myself the focus of successful aging discourse, I am exposed to them every day. Still, it has taken this research process for me to notice just how prevalent ageism and normative ideas of successful aging are around me.

I began my Ph.D. on the topic of aging in deep conversation with the elders in my own life; my grandmother, my godmother, my parents, my adoptive mothers and grandmothers, my aunts and uncles. These are the relationships in which I am grounded in this research and some of the relationships to which I strive to be accountable. Wilson, in the context of Indigenous research, speaks of relational accountability as being rooted in respect, reciprocity, and responsibility (2008: 77). This means being true

\footnotetext{
${ }^{5}$ By care institutions, I mean long-term care facilities as well as retirement homes and other assisted living institutions, both public and private.
} 
to the relationships from which my learning, unlearning, and relearning emerge. It also means that my insights do justice to these relationships and that they are useful. I furthermore see my role as a researcher working with older generations as a scribe of sorts. Returning to my motivations for pursuing my doctorate, I see value in bearing witness, in deep listening to the stories of older generations. As my research relationships continue to grow beyond my family, I will continue to be guided by relational accountability.

Having spent many months delving, as one does in the beginning of a Ph.D., into the cultural, medical, public health, policy, and economic discourses that surround aging, ageism, and wellbeing in later life, I wanted to look beyond the binary narrative of "success" and "failure" constructed within aging discourses across these fields (Lamb et al., 2017). Instead, I sought out examples of hopeful, wholehearted, and connected aging 6 that are not bound by dominant aging narratives. With my elders in mind, I had strong examples of what norm-defying aging could look like. I wanted to learn from those living their own understanding of aging well or otherwise.

I was able to do a few months of early data collection in Uruguay in mid-2019 to begin getting to know an inspiring network of older people, Uruguay's National network of elderly persons or Red Nacional de Personas Mayores (REDAM). The REDAM is a civil society network that brings together various groups and organizations around activism and advocacy for older people. They were active participants in the creation of the 2015 Inter-American Convention on Protecting the Human Rights of Older Persons. Members of the REDAM have more recently focused on a critique of the Sustainable Development Goals (SDGs), asking "where is the aging?" and identifying how they would like to be working at the intersection of care for older people and care for the environment. In their work, I have been greatly inspired by how members of the REDAM mobilize mainstream discourses of international human rights frameworks and the SDGs to carve out space for the kinds of aging and the kinds of activism they want.

\footnotetext{
${ }^{6}$ I would like to note that the adjectives I use here generally evoke positive connotations. I am not trying to paint aging with rose colored glasses, ignoring the difficult and painful realities of getting old. A politics of hope, and living in "connected" ways requires work, hard work.
} 
Getting to know members of the REDAM took me to several different regions of Uruguay. I was able to spend many slow afternoons, sharing tea or mate ${ }^{7}$ and listening to stories. These conversations often led to someone pulling out a few photos from their wallet or photo album. I am always grateful to be offered the stories of people's activist and personal lives told through photos. While many such stories centered on joyful and triumphant moments, struggle and hardship also figured prominently. In the context of happy and hard stories that wander and lead from one to the next, deep listening is a feminist methodology of choice. While exploring aging and sustainability with REDAM members, I was asking "not just 'what do I think about this?' but 'what does this mean to my life?"” (Freeland Ballantyne, 2012). I feel this is part of my relational responsibility for receiving these stories.

Having lost my maternal grandmother months earlier, my last grandparent, I was very happy to have a reason to be spending time with older women. Wilson says: "[ $\mathrm{t}]$ he source of a research project is the heart/mind of the researcher, and 'checking your heart' is a critical element in the research process" (2008: 60). Despite being on a different continent, thousands of kilometers from home, there was something so familiar, so comforting, about being in the company of wise women. This time allowed me to "check my heart". I use the term "wise" in order to describe these women not to evoke the trope that being older makes one necessarily wiser, but for two clear reasons. First, as a way of underscoring the value of the time these women chose to spend with me, sharing rich and meaningful reflections about the lives they've lived. Second, one of the goals of my research is to make visible the ways in which the knowledge and experience of older people is dismissed and devalued within academia and more broadly in many western societies. As such, I aim to be explicit about highlighting the importance of older people's knowledge.

Enmeshed with the affective layers of my fieldwork, I now realize that these experiences validated some of my unconscious and unexamined assumptions about my research-primarily that I am non-threatening. My positionality as a researcher in this context is necessarily layered with nationality, whiteness and education, knowing this meant the understandings I gained would necessarily be partial. Despite this, the people and collectives I met through the REDAM in Uruguay were very happy to

\footnotetext{
${ }^{7}$ Mate is an infused caffeinated bitter tea popular in Uruguay, Argentina, Paraguay and southern Brazil, shared often among friends.
} 
speak with me, they invited my questions, and were keen to showcase their work, their thinking, and most of all the stories of how they came to be working on care for the old and care for the environment. Not encountering much friction or resistance, I interpreted this as being "on track".

In the Uruguayan context, the strong Montevideo-interior divide also played a role in how my positionality was read. ${ }^{8}$ Because I was spending time with initiatives outside of Montevideo, I was aware that my interest was often read as validating the work of the people I was interviewing. Through this, I came to understand that my interest in these initiatives was being utilized to underscore the importance of their work; I was often asked to speak on television and radio with members of these groups to explain why I was interested in what was taking place. I was happy to be able to lend support in these kinds of ways and understood this as a form of reciprocity.

I returned to Uruguay at the end of February 2020 with plans to pick up the many connections and conversations that had begun nearly one year earlier. By mid-March, I was told by my university that I had to leave. 9

Covid-19 has made more visible many forms of ageism and age disparities around the world. It is important to examine who has had to bear the majority of the costs of both the pandemic and the consequences resulting from governmental pandemic responses. The death toll of the virus within long-term care institutions, where the majority of residents are elderly, has exposed the consequences of "warehousing seniors" in care facilities (Muscedere \& Williams, 2020), what aging studies scholar Stephen Katz calls "state-sponsored elder abuse" (Katz, 2020). More broadly, narratives of decline and vulnerability have, almost overnight, stripped an entire generation of their autonomy and agency in the name of protecting highrisk people (Ayalon et al., 2020; Ehni \& Wahl, 2020). And yet, as the pandemic drags on, the mental and physical consequences of loneliness and isolation are showing themselves.

\footnotetext{
${ }^{8}$ With roughly one third of the country's population living in Montevideo, and with a long history in disparities between the interior and the capital, the interior of Uruguay is sometimes overlooked. The urban/rural divide means those based in Montevideo often find themselves closer to the center of political, economic and cultural power.

${ }^{9}$ Being "evacuated" by the university made explicitly clear whose risk is valued by the university.
} 
For my own research, this has meant that I now encounter far less bewilderment when discussing my research topic; I no longer have to justify the importance of asking questions about aging and wellbeing in later life. As I will discuss in the conclusion, the consequences of the pandemic for older people have also meant that I recognize a certain level of urgency, with the consequences felt so disproportionately by older people, when thinking about how to do aging differently.

The far-reaching effects of the Covid-19 pandemic have made visible many of my assumptions and cast conversations about risk in research in a whole new light. This is what I turn to next.

\section{UNPACKING Assumptions}

Having defended my research design in mid-February, I had only been in Uruguay for a short time when Covid-19 became real for me. While there were not yet any cases of the virus in Uruguay in early March 2020, I realized that my research had become much more ethically complex. Was it ethical for me to continue connecting with potential research collaborators in person in light of the virus? What was the risk of transmission involved, particularly as my research relates to older people? Was it ethical to even suggest face-to-face interactions, when someone may have to weigh the risks of severe illness or death in order to meet with me?

I became physically threatening in the eyes of my research collaborators, and this reversal has put into relief this and other assumptions that have underpinned my research design. My early fieldwork experiences reinforced the narrative that I had constructed about who I am as a researcher and validated many underlying assumptions. Thinking through how Covid-19 has shifted my understandings, I am brought to confront these assumptions.

Looking back, I see that, despite setting out with the goal to be reflexive, I spent much more time thinking through the subjectivities of the people that I would do research with than truly thinking about how I am read and where I fit. Why was my being non-threatening so important to my project? I think this was the case, in part, because I thought that being with people would be the easy part. I have also come to understand that this process of reflection was cut short by my having to leave Uruguay. I am reminded of Sultana's description of the fluidity of positionality: " $[\mathrm{m}] \mathrm{y}$ experience has been that positionality and subjectivity are tempered both spatially and temporally, and are unstable and 
not fixed. Dynamics change with context" (Sultana, 2007: 382). Writing this chapter has served as a way for me to continue these processes of reflection.

I see now that I had also assumed that some people would want to talk to me. This assumption was based on my being a relatively young woman, interested in the life experiences of older people who aren't often heard. Compounded with whiteness and nationality, I had assumed that my interest would be enough for some to want to spend time with me. An extension of this is the assumption that someone would be pleased to participate in my research. I see now that I would have problematized this assumption in so many other contexts, but I hadn't questioned it here with regards to age. While I did meet and spend time with many people who were eager to share their stories of both triumph and frustration, and happy for me to spend time with them, there is a layer of discomfort for me in realizing this gap. I have had to continue to unpack the underlying thoughts about older people that enabled this assumption, and this experience has served as an important reminder that unlearning ageism is a perpetual process.

\section{REFLECTIONS ON RisK}

As I am sure it has for many, Covid-19 has also shifted my understanding of risk. Discourses of risk have been instrumentalized in many ways in this pandemic, particularly when it comes to older people.

$[\mathrm{W}] \mathrm{e}$ are seeing in public discourse an increasing portrayal of those over the age of 70 as being all alike with regard to being helpless, frail, and unable to contribute to society. These views are being spread by social media, the press, and public announcements by government officials throughout the world. (Ayalon et al., 2020: 1)

What are the consequences of representing entire generations in homogenizing ways? Who is at risk? Whose risk matters? What kinds of risks are centered? What does risk hide?

In research, for whom is risk being considered? The focus of discussions about risk within the research institute where I am based revolve around a place, such as a geographical location, or a context, such as war or disaster, being risky. A researcher inserts themselves into this place or context. Where vulnerability of research participants is discussed, what is 
taken into account are circumstances or contexts which make participants "vulnerable", such as the difficulty of informed consent when dealing with research participants who live with cognitive impairment. What about the risk that you, as a researcher, bring with you to a place, to people, or to relationships? Going back to Linda Tuhiwai Smith's "research as dirty," this speaks to the risks the researcher represents, the risks I bring with me as a researcher.

\section{Concluding Thoughts}

Now, one year later, we know more about the virus, about how it spreads, how to diminish risks of transmission; we are beginning to see the effects of vaccine rollout. And yet, it is still very unclear what the post-pandemic world will look like and feel like.

This has been a necessary period of unlearning and relearning for me. This has also served as an important reminder that even with commitments to feminist research ethics and principles of mutuality in research, even while trying to do things differently, I get things wrong. We all come to research with gaps. The question then becomes how do I build research practices of noticing my own unconscious assumptions? And how does this add to conversations about feminist research methodologies more broadly?

Feminist ethics in research is understood as always in process; it is a commitment to continuing to work through the messiness of asking questions. This sometimes means making visible one's own clumsiness, as I have attempted to do here. Decolonial approaches to ethics remind us about relational accountability and ensuring mutuality in the research process. Resisting the narrow understandings of institutional review processes, we can choose more ample understandings of ethics.

While the virus has made the need to rethink wellbeing in later life painfully clear, I feel compelled to ask more immediately change-oriented questions. By change-oriented I mean that the pace at which Covid-19 is changing how lives are lived, or making visible unjust logics dominant in society, is not compatible with the markedly slow pace of academia. I feel now more than ever that the academic work I am able to do at the moment must be coupled with more tangible contributions to justiceseeking processes-because academia functions in temporalities not always compatible with human lives. 
As the pandemic wears on, I have also begun to question some of the assumptions I made early on in the pandemic. Is distancing myself from older people, because they are more at risk of Covid-19, denying older people's agency? What of the consequences of staying away? In the first weeks of the pandemic, I was confronted by the question of whether it is ethical to see people. I now wonder whether it is ethical to not see people.

Acknowledgements I would like to thank Wendy Harcourt, Rosalba Icaza, Zuleika Sheik, along with my co-editors and contributors to this book for fruitful exchanges that have helped me further my reflections. Any errors or omissions remain my own.

Funding My work has received funding from the European Union's Horizon 2020 research and innovation program under the Marie Skłodowska-Curie grant agreement No. 764908 WeGO-ITN on "Well-being, Ecology, Gender, and cOmmunity-Innovation Training Network".

\section{REFERENCES}

Ayalon, L., Chasteen, A., Diehl, M., Levy, B. R., Neupert, S. D., Rothermund, K., Tesch-Römer, C., \& Wahl, H.-W. (2020). Aging in times of the COVID19 pandemic: Avoiding ageism and fostering intergenerational solidarity. The Journals of Gerontology: Series B, 718; 6(2), e49-e52.

Bradley, M. (2007). Silenced for their own protection: How the IRB marginalizes those it feigns to protect. ACME: An International Journal for Critical Geographies, 6(3), 339-349.

Cahill, C., Sultana, F., \& Pain, R. (2007). Participatory ethics: Politics, practices, institutions. ACME: An International Journal for Critical Geographies, 6(3), 304-318.

Calasanti, T., Slevin, K. F., \& King, N. (2006). Ageism and feminist: From "Et Cetera" et center. National Women's Studies Association Journal, 18(1), $13-30$.

Collins, P. H. (1986). Learning from the outsider within: The sociological significance of black feminist thought. Social Problems, 33(6), 14-32.

Escobar, A. (2007). World and knowledges otherwise. The Latin American Modernity/Coloniality Research Program. Cultural Studies, 21(2), 179-210.

Fabbre, V. D. (2015). Gender transitions in later life: A queer perspective on successful aging. The Gerontologist, 55, 144-153. 
Freeland Ballanyne, E. (2012). Intergenerational equity \& decolonization: An argument for love in an era of rapid environmental change. $18^{\text {th }}$ International Symposium on Society and Resource Management, University of Alberta posted on August 13. Retrieved May 10, 2015, from https://www.youtube.com/ watch? $=0$ OEa_gV86jfc.

Halse, C., \& Honey, A. (2005). Unraveling ethics: Illuminating the moral dilemmas of research ethics. Signs, 30(4), 2141-2162.

Ehni, H. J., \& Wahl, H. W. (2020). Six propositions against ageism in the COVID-19 pandemic. Journal of Aging \& Social Policy, 32(4-5), 515-525.

Haraway, D. (1988). Situated knowledges: The science question in feminism and the privilege of partial perspective. Feminist Studies, 14(3), 575-599.

Harcourt, W., \& Nelson, I. L. (2015). Introduction: Are we "green" yet? And the violence of asking such a question. In W. Harcourt \& I. L. Nelson (Eds.), Practising feminist political ecologies: Moving beyond the "green economy" (pp. 1-28). Zed Books.

Harding, S. (1995). "Strong Objectivity": A response to the new objectivity question. Feminism and Science, 104(3), 331-349.

Hooks, B. (1994). Teaching to transgress: Education as the practice of freedom. Routledge.

Icaza, R. (2017). Decolonial feminist and global politics: Border thinking and vulnerability as a knowing otherwise. In M. Woons \& S. Weier (Eds.), Critical epistemologies of global politics (pp. 26-45). E-International Relations Publishing.

Katz, S. (2020, March 2). When are we going to reword what's happening in Ontrio as state-sponsored elder abuse and ageist violence? [Tweet]. Twitter. Retrieved March 21, 2021, from https://twitter.com/stephen_skatz/status/ 1366803944249434114 ? $\mathrm{s}=21$.

Katz, S., \& Calasanti, T. (2015). Critical perspectives on successful aging: Does it "Appeal More Than It Illuminates"? The Gerontologist, 55, 26-33.

Lamb, S., Robbins-Ruszkowski, J., \& Corrwin, A. I. (2017). Introduction: Successful aging as a twenty-first-century obsession. In S. Lamb (Ed.), Successful aging as a contemporary obsession: Global perspectives (pp. 1-24). Rutgers University Press.

Millora, C., Maimunah, S., \& Still, E. (2020). Reflecting on the ethics of PhD research in the Global South: Reciprocity, reflexivity and situatedness. Acta Academica: Critical views on society, culture and politics, 52(1), 10-30.

Muscedere, J., \& Williams, R. (2020). It's time to stop warehousing seniors in long-term care. Retrieved January 20, 2021, from https://www.healthing.ca/ opinion/its-time-to-stop-warehousing-seniors-in-long-term-care.

Ranzijn, R. (2010). Active ageing-Another way to oppress marginalized and disadvantaged elders? Aboriginal elders as a case study. Journal of Health Psychology, 15, 716-723. 
Rubinstein, R. L., \& de Medeiros, K. (2015). “Successful Aging”, Gerontological Theory and Neoliberalism: A qualitative critique. The Gerontologist, 55, 34-42. Sandberg, L. J., \& Marshal, B. L. (2017). Queering aging futures. Societies, 7(3), 21.

Smith, L. T. (2012). Decolonizing methodologies: Research and indigenous peoples. Zed Books.

Sultana, F. (2007). Reflexivity, positionality and participatory Ethics: Negotiating Fieldwork Dilemmas in International Research. ACME: An International Journal for Critical Geographies, 6(3), 374-385.

Tuck, E., \& Guishard, M. (2013). Uncollapsing ethics: Racialized sciencism, settler coloniality, and ethical framework of decolonial participatory action research. In T. M. Kress, C. S. Malott, \& B. J. Porfilio (Eds.), Challenging Status Quo Retrenchment: New Directions in Critical Research (pp. 3-27). Information Age Publishing.

Tuck, E., \& Yang, K. W. (2014). R-words: Refusing research. In D. Paris \& M. T. Winn (Eds.), Humanizing research: Decolonializing qualitative inquiry with youth and communities (pp. 223-247). Sage.

Walsh, C. (2012). Other" Knowledges, "Other" critiques: Reflections on the politics and practices of philosophy and decoloniality in the "Other" America. Transmodernity, 1(3), 11-27.

Walsh, C. (2016). On gender and its "Otherwise." In W. Harcourt (Ed.), The Palgrave handbook of gender and development (pp. 34-47). Palgrave Macmillan.

Wellin, C. (2018). Critical gerontology comes of age: Advances in research and theory for a new century. Routledge.

Wilson, S. (2008). Research is ceremony: Indigenous research methods. Fernwood Publishing. 
Open Access This chapter is distributed under the terms of the Creative Commons Attribution 4.0 International License (http://creativecommons.org/ licenses/by/4.0/), which permits use, duplication, adaptation, distribution and reproduction in any medium or format, as long as you give appropriate credit to the original author(s) and the source, a link is provided to the Creative Commons license and any changes made are indicated.

The images or other third party material in this chapter are included in the work's Creative Commons license, unless indicated otherwise in the credit line; if such material is not included in the work's Creative Commons license and the respective action is not permitted by statutory regulation, users will need to obtain permission from the license holder to duplicate, adapt or reproduce the material.

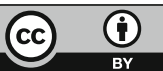

